\title{
Perlindungan Penduduk Sipil Saat Terjadi Konflik Bersenjata Berdasarkan Hukum Humaniter Internasional dan Hukum Pertahanan Indonesia
}

\author{
Herman Suryokumoro, Ikaningtyas \\ Fakultas Hukum Universitas Brawijaya \\ hermans-fh@ub.ac.id
}

Submit: 16-09-2020; Review: 04-12-2020; Terbit: 12-12-2020

\begin{abstract}
International legal instruments have regulated the issue of armed conflict, including national defense issues known as International Humanitarian Law. Indonesia itself has tried to deal with the nation's security issues comprehensively. These efforts are balanced with efforts to build a sense of nationality, social, political and economic systems. In developing national security, this nation has developed the Universal People's Defense and Security System (Sishankamrata), Wawasan Nusantara and National Defense.. Humanitarian law is codified in: First, Hague Law. Second, Geneva Law. The protection of the civilian population is regulated separately in Geneva Convention IV. And third, other International Legal Instruments, namely the provisions of humanitarian law apart from the provisions of Hague Law and Geneva Law. meanwhile, legal protection for civilians during armed conflict based on the National Defense System in Indonesia, refers to the provisions of protection of human rights in general. this is found in the arrangements in the 1945 Constitution, as well as Law Number 56 of 1999 concerning Trained People. While in Law Number 27 of 1997 concerning Mobilization and Demobilization and Law Number 3 of 2002 concerning National Defense
\end{abstract}

Keywords: Protection, Civillians, Humanitarian Law, National Security.

\begin{abstract}
Abstrak
Instrumen hukum internasional telah mengatur ketentuan mengenai pertahanan yang terkait dengan permasalahan perang yang disebut dengan Hukum Humaniter Internasional. Indonesia sendiri telah berupaya menangani persoalan survival bangsa ini secara komprehensif. Upaya tersebut diimbangi dengan upaya membangun rasa kebangsaan, sistem sosial, politik dan ekonomi untuk mengisi kemerdekaan tersebut. Dalam membangun national security, bangsa ini telah mengembangkan Sistem Pertahanan dan Keamanan Rakyat Semesta (Sishankamrata), Wawasan Nusantara (Wanus) dan Ketahanan Nasional. Perlindungan hukum bagi penduduk sipil pada saat konflik bersenjata dalam instrumen hukum internasional diatur dalam ketentuan yang disebut Hukum Humaniter Internasional. Hukum humaniter tersebut dikodifikasi ke dalam Pertama, Hukum Den Haag. Kedua, Hukum Jenewa. Perlindungan penduduk sipil diatur tersendiri dalam Konvensi IV Jenewa. ketiga, Instrumen Hukum
\end{abstract}


Internasional lainnya yakni ketentuan diluar dari ketentuan Hukum Den Haag maupun Hukum Jenewa. Sedangkan, perlindungan hukum bagi penduduk sipil pada saat konflik bersenjata berdasarkan Sistem Pertahanan Negara di Indonesia mengacu kepada ketentuan perlindungan terhadap hak asasi manusia (HAM) secara umum yang diatur di dalam Undang-Undang Dasar 1945, Undang-Undang Nomor 56 Tahun 1999 tentang Rakyat Terlatih, Undang-Undang Nomor 27 Tahun 1997 tentang Mobilisasi dan Demobilisasi, serta Undang-Undang Nomor 3 Tahun 2002 tentang Pertahanan Negara.

\section{Kata kunci: Perlindungan, Penduduk Sipil, Hukum Humaniter, Pertahanan Nasional.}

\section{Pendahuluan}

Dalam dinamisasi hukum Internasional yang kerap mengalami paradox hingga saat ini adalah eksistensi mengenai Hukum Humaniter Internasional (HHI). Paradox dikarenakan kelompok negasi berpendapat bahwa keberadaan $\mathrm{HHI}$ justru bertentangan dengan hukum itu sendiri. Hukum yang tujuannya untuk mengatur harmonisasi hubungan antara subyek hukum, tidak terrepresentasi dalam HHI yang justru melegalisasi penggunaan kekerasan dalam perang Mohammed Bedjaoui menyatakan bahwa Hukum Humaniter ini terbentuk karena alasan-alasan yang bersifat pragmatis saja; yakni menerima bahwa kenyataannya memang perang tetap akan terjadi hingga entah kapan, tidak seorangpun dapat menentukan. Menurut Bedjaoui, Hukum Humaniter hanya mencoba untuk mengatur agar suatu perang dapat dilakukan dengan lebih memperhatikan prinsip-prinsip kemanusiaan, sehingga tujuannya adalah semata-mata untuk memanusiawikan peperangan dan sama sekali tidak berusaha untuk mencegahnya. Oleh karena itu, setidaknya Hukum Humaniter ini bertujuan untuk (Arlina Permanasari, 1999:11) :

1) Memberikan perlindungan terhadap kombatan maupun penduduk sipil dari penderitaan yang tidak perlu (unnecessary suffering);

2) Menjamin hak asasi manusia (HAM) yang sangat fundamental 
bagi mereka yang jatuh ke tangan musuh. Kombatan yang jatuh ke tangan pihak musuh harus diperlakukan sebagai tawanan perang dan mendapat perlindungan hukum yang semestinya menurut Konvensi Jenewa III 1949;

3) Mencegah dilakukannya perang secara kejam tanpa mengenal batas.

Secara garis besar HHI bertujuan : melindungi fisik dan mental, baik pihak kombatan maupun pihak sipil dari penderitaan yang tidak perlu, menjamin hak-hak asasi manusia tertentu dari orang yang jatuh ke tangan musuh, memungkinkan dikembalikannya perdamaian, membtasai kekuasaan piha yang berperang (Teguh Sulista, 2007:535)

Instrumen hukum internasional telah mengatur ketentuan mengenai pertahanan yang terkait dengan permasalahan perang yang disebut dengan Hukum Humaniter Internasional. Hukum Humaniter Internasional merupakan bentuk pertanggungjawaban secara hukum terhadap siapa saja yang melakukan pelanggaran dalam etika berperang. Hukum Humaniter merupakan perangkat yuridis dalam penerapan perang yang berkeadilan baik dari pihak yang terlibat dalam konflik tersebut maupun bagi pihak yang tidak terlibat di dalamnya. Hukum Humaniter bertujuan untuk mengurangi penderitaan akibat perang. Dikatakan bahwa hak-hak korban perang yang dilindungi hukum humaniter adalah hak-hak asasi manusia yang fundamental. Disamping itu, untuk tujuan perlindungan, hukum humaniter dilengkapi dengan ketentuan-ketentuan tentang pembatasan atau larangan terhadap penggunaan alat-alat dan caracara peperangan tertentu (Rina Rusman, 2004:2).

Aturan perang modern kini dikompilasi dalam 4 Konvensi Jenewa tahun 1949 dan telah diratifikasi oleh mayoritas negara di dunia. Perjanjian-perjanjian awal ini penting untuk melacak sejauh mana aturan yang beragam itu dimasukkan dalam hukum internasional, sebagai prinsip yang merujuk fakta-fakta yang ada, namun tetap independen. Ini dikenal dengan 
nama Klausula Marten (Geoffrey Robertson QC, 2002: 214). Dalam Konvensi Jenewa tahun 1949 dikenal sebuah prinsip dasar dalam penyelenggaraan perang oleh suatu negara yakni prinsip pembedaan (Distinction Principle). Prinsip ini merupakan asas yang membedakan atau membagi penduduk dari suatu negara yang sedang berperang atau sedang terlibat dalam konflik bersenjata ke dalam dua golongan, yaitu kombatan (Combatan) dan penduduk sipil (Civilian). Ketika menegakkan perlindungan yang diberikan kepada warga sipil,tidak boleh ada diskriminasi. Pasal 13 Konvensi Jenewa IV 1949 menegaskan bahwa "Seluruh penduduk dari negaranegara yang bersengketa, tanpa perbedaan yang merugikan apapun yang didasarkan atas suku, kebangsaan, agama, atau pendapat politik,dan dimaksudkan untuk meringankan penderitaan yang disebabkan oleh perang”. Sehingga, prinsip perbedaan memberikan kekebalan terhadap penduduk sipil,dan obyek sipil (Danial, 2016:2).
Indonesia sendiri telah berupaya menangani persoalan survival bangsa ini secara komprehensif. Upaya tersebut diimbangi dengan upaya membangun rasa kebangsaan, sistem sosial, politik dan ekonomi untuk mengisi kemerdekaan tersebut. Dalam membangun national security, bangsa ini telah mengembangkan 3 doktrin utama yaitu adalah Sistem Pertahanan dan Keamanan Rakyat Semesta (Sishankamrata), Wawasan Nusantara (Wanus) dan Ketahanan Nasional. Ketiga doktrin ini merupakan upaya mengatasi berbagai kelemahan yang dimiliki.

Sishankamrata mendapat legitimasi dalam Undang-Undang Dasar 1945 (UUD 1945) pasal 30 ayat 2 yang menyatakan bahwa "usaha pertahanan dan keamanan negara dilaksanakan melalui sistem pertahanan dan keamanan rakyat semesta oleh Tentara Nasional Indonesia dan Kepolisisan Negara Republik Indonesia sebagai kekuatan utama dan rakyat sebagai kekuatan pendukung”. Juga dalam UndangUndang Nomor 3 Tahun 2002 tentang 
Pertahanan Negara pasal 1 ayat 2 bahwa

"Sistem pertahanan negara adalah sistem pertahanan yang bersifat semesta yang melibatkan seluruh warga negara, wilayah, dan sumber daya nasional lainnya, serta dipersiapkan secara dini oleh pemerintah dan diselenggarakan secara total, terpadu, terarah, dan berlanjut untuk menegakkan kedaulatan negara, keutuhan wilayah, dan keselamatan segenap bangsa dari segala ancaman".

Dalam pemberlakuan doktrin sishankamrata, terdapat potensi kekerasan militer yang dapat muncul yakni Pertama, pelibatan rakyat secara luas dalam komponen pertahanan keamanan mencabut imunitas yang dijamin oleh Konvensi Jenewa. Kedua, doktrin ini cenderung mengabaikan syarat proporsionalitas. Salah satu bentuk kerugian perang yang jarang mendapat perhatian serius adalah "kerusakan" segi psikis masyarakat yang tidak siap menerima trauma yang timbul akibat perang. Ketiga, Sishankamrata juga memungkinkan TNI untuk membelokkan konsep demokratis supremasi sipil menjadi supremasi rakyat. Hal ini mengindikasikan bahwa TNI tidak perlu selalu tunduk kepada keputusan eksekutif jika itu dirasa tidak sejalan dengan apa yang dianggap TNI sebagai suara rakyat. Keempat, doktrin ini dapat menimbulkan konflik horizontal antar kelompok masyarakat jika pertikaian yang terjadi bukan antar negara namun antara negara melawan gerakan separatis atau konflik antara kelompok dalam masyarakat. Dan kelima doktrin ini membutuhkan dukungan penuh dari masyarakat, dukungan itu bisa didapat dengan membentuk perasaan identitas kolektif yang bersifat instan yang menempatkan emosi-emosi kaum chauvinis. Dengan kata lain aktor militer akan berusaha untuk merekayasa nasionalitas bangsanya melalui proses indoktrinasi yang sistematis (Andi Widjajanto, 2000:12).

Undang-Undang Nomor 3 Tahun 2002 tentang Pertahanan Negara pasal 1 ayat 5, 6 dan 7 menyebutkan pembagian pihak-pihak yang terlibat dalam penyelenggaraan pertahanan negara yaitu Komponen utama adalah Tentara Nasional Indonesia, 
Komponen cadangan, komponen pendukung

Lebih lanjut disebutkan dalam pasal 8 ayat 1 dan 2 yang menyatakan :

1) Komponen cadangan, terdiri atas warga negara, sumber daya alam, sumber daya buatan, serta sarana dan prasarana nasional yang telah disiapkan untuk dikerahkan melalui mobilisasi guna memperbesar dan memperkuat komponen utama.

2) Komponen pendukung, terdiri atas warga negara, sumber daya alam, sumber daya buatan, serta sarana dan prasarana nasional yang secara langsung atau tidak langsung dapat meningkatkan kekuatan dan kemampuan komponen utama dan komponen cadangan.

Penyelenggaraan sistem pertahanan di negara ini didasarkan pada pembagian komponen-komponen yang terdiri komponen utama, komponen cadangan dan komponen pendukung. Artinya keberadaan masing-masing komponen berada dalam satu kesatuan fungsi dan komando pertahanan negara. Hal ini yang menyebabkan bertentangan karena dalam distinction principle para pihak yang terlibat terpisahkan pada fungsi mereka masing-masing secara jelas dan tegas. Tidak adanya pembedaan berdasarkan distinction principle dalam sistem pertahanan di Indonesia menyebabkan hilangnya jaminan perlindungan hukum terhadap masyarakat sipil di Indonesia yang diatur dalam ketentuan hukum internasional. Disamping itu, Indonesia sendiri telah meratifikasi Konvensi Jenewa tahun 1949 dengan keluarnya Undang-Undang Nomor 59 tahun 1958 tentang ikut serta Negara Republik Indonesia dalam seluruh Konvensi Jenewa tanggal 12 Agustus 1949.

Dalam UUD 1945 dengan tegas dan jelas menyatakan bahwa kewajiban sebuah negara harus memberikan perlindungan terhadap warganegaranya. Seperti yang dirumuskan dalam Pasal 28A sampai dengan 28J secara singkat juga mengamanahkan perlindungan terhadap Hak Asasi Manusia warga negara di negeri ini. Jaminan 
perlindungan hukum kepada penduduk sipil dalam membangun sistem pertahanan negara merupakan bagian dari tanggung jawab negara secara keseluruhan yakni mewujudkan citacita dasar perjuangan negara ini yang menjunjung tinggi nilai-nilai dasar kemanusiaan, demokrasi dan keadilan sosial. Dalam konteks ini negara pun harus bertanggung jawab dengan memberikan jaminan perlindungan bagi penduduk sipil di Indonesia

Dari latar belakang yang telah dipaparkan diatas maka pokok permasalahan adalah Bagaimana bentuk perlindungan hukum bagi penduduk sipil ketika terjadi konflik bersenjata berdasarkan hukum humaniter internasional dan Hukum pertahanan Indonesia?.

\section{Metode Penelitian}

Sesuai dengan pemrmasalahan yang akan dibahas maka penelitian ini merupakan Yuridis Normatif, yaitu Penelitian hukum yang dilakukan dengan cara meneliti bahan pustaka atau data sekunder belaka atau disebut dengan Penelitian Hukum Kepustakaan
(Soerjono Soekanto, 1990:38). Penelitian Yuridis Normatif adalah penelitian yang mengkaji pokok permasalahan berdasarkan kaidah hukum dan norma hukum yang ada di dalam hukum Positif. Peter Mahmud Marzuki mengemukakan bahwa, penelitian hukum adalah suatu proses untuk menemukan aturan hukum, prinsip-prinsip hukum maupun doktrindoktrin hukum guna menjawab isu hukum yang dihadapi, dan keberadaan penelitian hukum dilakukan untuk menghasilkan argumentasi, teori atau konsep baru sebagai preskripsi dalam menyelesaikan masalah yang dihadapi, sehingga jawaban yang diharapkan di dalam penelitian hukum adalah right, appropriate, inappropriate atau wrong (Peter Mahmud Marzuki, 2005: 35)

Dalam Penelitian ini bahan hukum yang digunakan:

a) Bahan Hukum Primer meliputi Konvensi Den Haag 1899, Konvensi Den Haag 1907, Deklarasi Universal Hak Asasi Manusia Tahun 1948., Konvensi Jenewa Tahun 1949, Protokol Tambahan Tahun 1977, Undang- 
Undang Dasar Republik Indonesia Tahun 1945, Undang-Undang Nomor 59 Tahun 1958, UndangUndang Nomor 27 Tahun 1997, Undang-Undang Nomor 56 Tahun 1999 ,

b) Bahan Hukum Sekunder, yaitu bahan hukum yang memberikan penjelasan mengenai bahan hukum Primer

c) Bahan Hukum Tersier, yaitu bahan hukum yang memberikan petunjuk maupun penjelasan terhadap bahan hukum primer dan sekunder seperti:

1) Kamus Istilah Aneka Hukum.

2) Kamus Bahasa Inggris.

3) Black Law Dictionary

\section{Hasil dan Pembahasan}

\section{Perlindungan Hukum Bagi}

Penduduk Sipil ketika terjadi konflik bersenjata berdasarkan Hukum

\section{Humaniter}

Dalam Konflik bersenjata, para pihak yang berperang akan sangat dimungkinkan untuk tidak mengindahkan aturan dalam HHI khususnya mengenai perlindungan sipil (Anastsya Y.Turlel, 2017:147). Hal ini dikarenakan memenangkan konflik bersenjata menjadi prioritas utama para pihak sehingga mengesampingkan kemanusiaan (Rotem Giladi, 2014:847). Perangkat HHI sendiri telah memberikan payung hukum bagi perlindungan penduduk sipil, baik dalam Konvensi Den Haque maupun dalam Konvensi Jenewa 1949.

\section{a) Berdasarkan Den Haque Regulations}

Hukum Den Haag merupakan ketentuan hukum humaniter yang mengatur mengenai cara dan alat berperang. Hukum Den Haag terdiri dari hasil Konferensi Perdamaian I pada tahun 1899 yang lebih dikenal dengan Konvensi Den Haag 1899 dan Konferensi Perdamaian II pada tahun 1907 yang dikenal dengan Konvensi Den Haag 1907.

Di dalam Konvensi Den Haag 1899 dihasilkan 3 konvensi dan 3 deklarasi. 3 konvensi itu adalah : 
1) Konvensi I tentang Penyelesaian Damai Persengketaan Internasional.

2) Konvensi II tentang Hukum dan Kebiasaan Perang di Darat.

3) Konvensi III tentang Adaptasi Asas-asas Konvensi Jenewa Tanggal 22 Agustus 1864 tentang Hukum Perang di Laut.

Dalam Konvensi Den Haag 1907 yang merupakan kelanjutan dari Konvensi Den Haag 1899 menghasilkan beberapa konvensi :

a) Konvensi I tentang Penyelesaian Damai Persengketaan Internasional.

b) Konvensi II tentang Pembatasan Kekerasan Senjata dalam Menuntut Pembayaran Hutang yang Berasal dari Perjanjian Perdata.

c) Konvensi III tentang Cara Memulai Peperangan.

d) Konvensi IV tentang Hukum dan Kebiasaan Perang di Darat dilengkapi dengan Peraturan Den Haag.

e) Konvensi $\mathrm{V}$ tentang Hak dan Kewajiban Negara dan Warga Negara Netral dalam Perang di Darat.

f) Konvensi VI tentang Status Kapal Dagang Musuh pada saat Permulaan Perang.

g) Konvensi VII tentang Status Kapal Dagang menjadi Kapal Perang.

h) Konvensi VIII tentang Penempatan Ranjau Otomatis di dalam Laut. i) Konvensi IX tentang Pemboman oleh Angkatan Laut di Waktu Perang.

j) Konvensi $X$ tentang Adaptasi Asas-asas Konvensi Jenewa tentang Perang di Laut.

k) Konvensi XI tentang Pembatasan Tertentu terhadap Penggunaan Hak Penangkapan dalam Perang Angkatan Laut.

1) Konvensi XII tentang Mahkamah Barang-barang Sitaan.

m) Konvensi XIII tentang Hak dan Kewajiban Negara Netral dalam Perang di Laut.

Perlindungan hukum yang diberikan kepada penduduk sipil di dalam konvensi ini, baik Konvensi Den Haag tahun 1899 maupun tahun 1907 tidak disebutkan secara langsung ditujukan kepada penduduk sipil. Adanya pembatasan penggunaan senjata yang berbahaya di dalam tubuh, larangan penggunaan gas beracun yang dapat mengakibatkan penderitaan yang berlebihan bagi korban, pembatasan penggunaan proyektil dan bahan peledak, serta adanya aturan tersendiri dalam melakukan perang adalah langkah antisipasi terhadap tindakan perang yang tidak tunduk pada nilainilai kemanusiaan. Dalam hal ini keterlibatan penduduk sipil 
dimungkinkan terjadi meskipun

tidak memiliki pertahanan termasuk dalam pihak yang tidak boleh diserang. Artinya secara tidak langsung dengan adanya pembatasan tersebut maka memberikan perlindungan kepada penduduk sipil, dan juga pihak lainnya yang tidak termasuk dalam peperangan.

Perlindungan diberikan dalam hal pengaturan cara berperang, larangan terhadap penggunaan racun, serangan kepada prajurit yang menyerah, membunuh prajurit yang sudah terluka secara curang atau memakai senjata yang menyebabkan penderitaan berlebihan, larangan menggunakan rumah sakit, tempat ibadah, universitas dan bangunan bersejarah untuk kepentingan militer, larangan menyerang kota yang tanpa memiliki pertahanan.

Seluruh negara diwajibkan untuk memperlakukan tawanan secara manusiawi, mengizinkan mereka untuk menyimpan barang-barang pribadi, beribadah dan membebaskan petugas dari tugas-tugas yang berhubungan dengan dinas militer. Selain itu juga larangan menyerang pelabuhan yang menghormati kekebalan yang dimiliki kapal yang berfungsi sebagai rumah sakit, kapal nelayan dan kapal dari pihak yang netral.

Perlindungan itu pun dipertegas dalam prinsip konvensi ini yakni :

"Bahwa hak negara yang sedang berperang untuk melukai musuhnya harus dibatasi dengan cara menghindari perlakuan atau penggunaan cara-cara yang mengakibatkan penderitaan berlebihan, baik cara-cara yang belum digunakan atau yang secara umum dianggap tidak manusiawi".

b) berdasarkan Hukum Jenewa

Hukum Jenewa terdiri dari beberapa perjanjian pokok pada tahun 1949 yang kemudian lebih dikenal dengan Konvensi Jenewa 1949. Hukum Jenewa merupakan ketentuan yang mengatur perlindungan korban perang yang terdiri dari beberapa konvensi yaitu :

1) Konvensi I tentang Perbaikan Keadaan Anggota Angkatan Perang yang Luka dan Sakit di Medan Pertempuran Darat.

2) Konvensi II tentang Perbaikan Keadaan Anggota Angkatan Perang di Laut yang Luka, Sakit dan Korban Karam. 
3) Konvensi III tentang Perlakuan Tawanan Perang.

4) Konvensi IV tentang Perlindungan Orang-orang Sipil di Waktu Perang.

Perlindungan penduduk sipil diatur tersendiri di dalam Konvensi Jenewa 1949 pada Konvensi ke-IV. Konvensi yang menjadi pedoman dalam hal memberikan perlindungan kepada penduduk sipil di waktu perang. Sebagaimana disebutkan dalam pasal 4

Konvensi :

"Orang-orang yang dilindungi oleh konvensi adalah mereka yang dalam suatu sengketa bersenjata atau peristiwa pendudukan, pada suatu saat tertentu dan dengan cara bagaimanapun juga, ada dalam tangan satu Pihak dalam sengketa atau kekuasaan pendudukan yang bukan negara mereka."

Namun ada pengecualian seperti yang disebutkan dalam lanjutan pasal 4 tersebut yakni :

"Warga negara suatu negara yang tidak terkait oleh konvensi tidak dilindungi oleh konvensi. Warga negara suatu negara netral yang tidak ada di wilayah suatu negara yang berperang, tidak akan dianggap sebagai orang-orang yang dilindungi, selama negara mereka mempunyai perwakilan diplomatik biasa di negara dalam tangan mana mereka berada."

Perlindungan tidak diberikan kepada penduduk sipil suatu negara yang negaranya tidak ikut serta (ratifikasi) dalam konvensi ini, serta penduduk sipil suatu negara netral yang memiliki perwakilan diplomatik di negara yang bersengketa. Hal ini mengacu bahwa ketentuan hukum internasional dapat diberlakukan bagi negara-negara yang menyetujui dan ikut serta di dalamnya dengan melakukan ratifikasi terhadap hasil kesepakatan internasional. Hal ini sesuai dengan prinsip kedaulatan yang merupakan salah satu prinsip utama dalam pembentukan ketentuan Hukum Internasional. Oleh karena itu persetujuan pemberlakuan hukum internasional itu tergantung sepenuhnya kepada persetujuan yang diberikan oleh setiap negara, serta juga kepada kebebasan dari masing-masing individu dan negara untuk melaksanakan ketentuan hukum internasional tersebut atau tidak. Namun disini negara masih mempunyai peranan yang cukup kuat melihat 
kedaulatan yang dimiliki oleh setiap negara terhadap keseluruhan sistem hukum internasional.

Dalam konvensi ini dimulai dengan 3 pasal penting yang memiliki kesamaan antara satu sama lain. Pertama, tuntutan agar konvensi ini ditaati dalam situasi apapun. Artinya tidak ada negara yang boleh melanggar konvensi karena alasan pertahanan negara, misalnya. Kedua, konvensi ini tidak hanya mengatur perang, tetapi juga konflik antar kelompok bersenjata. Ketiga, konvensi ini juga mewajibkan negara penandatangan untuk patuh meski musuhnya tidak atau belum menandatangani konvensi. Hal penting lainnya dalam konvensi ini adalah kewajiban negara-negara penandatangan untuk mengadili individu yang diduga melanggar dengan mendakwa mereka sesuai dengan pasal yang diatur dalam ketentuan konflik bersenjata internasional (Geoffrey Robertson QC, 2002:219-220).

Pada pasal-pasal berikutnya Konvensi Jenewa juga mengatur tentang perlindungan umum yang diberikan kepada penduduk sipil seperti dalam table 1 berikut ini :

Tabel 1

Perlindungan Penduduk Sipil dalam Konvensi Jenewa IV tahun 1949 tentang Perlindungan Orang-orang Sipil di Waktu Perang

\begin{tabular}{ccl}
\hline No & Pasal & \multicolumn{1}{c}{ Perlindungan yang diberikan } \\
\hline 1 & $\mathbf{1 4}$ & $\begin{array}{l}\text { Perlindungan kepada penduduk yang luka, sakit, orang-orang tua, } \\
\text { anak-anak dibawah usia 15 tahun, wanita-wanita hamil serta ibu-ibu } \\
\text { dari anak di bawah usia } 7 \text { tahun. }\end{array}$ \\
\hline 2 & $\mathbf{1 5}$ & $\begin{array}{l}\text { a. Perlindungan kepada kombatan atau non kombatan yang luka dan } \\
\text { sakit. }\end{array}$ \\
& b. $\begin{array}{l}\text { Perlindungan kepada orang-orang sipil yang tidak turut serta } \\
\text { dalam permusuhan dan tidak melakukan pekerjaan yang bersifat } \\
\text { militer. }\end{array}$ \\
\hline 3 & $\mathbf{1 6}$ & $\begin{array}{l}\text { Perlindungan bagi yang luka, sakit, mereka yang lemah serta wanita- } \\
\text { wanita hamil. }\end{array}$ \\
\hline
\end{tabular}




\begin{tabular}{|c|c|c|}
\hline 4 & 17 & $\begin{array}{l}\text { Perlindungan dalam hal pemindahan yang luka, sakit yang lemah dan } \\
\text { orang-orang tua, anak-anak dan wanita hamil dari daerah-daerah yang } \\
\text { diserang atau terkepung. }\end{array}$ \\
\hline 5 & 18 & Perlindungan terhadap rumah sakit sipil. \\
\hline 6 & 21 & $\begin{array}{l}\text { Perlindungan iring-iringan kendaraan atau kereta api yang khusus } \\
\text { disediakan di laut, yang mengangkut orang sipil yang luka dan sakit, } \\
\text { yang berbadan lemah dan wanita hamil. }\end{array}$ \\
\hline 7 & 22 & $\begin{array}{l}\text { Perlindungan bagi pesawat terbang yang khusus dipergunakan untuk } \\
\text { pemindahan orang-orang sipil yang luka dan sakit, yang berbadan } \\
\text { lemah dan wanita hamil atau untuk pengangkatan petugas dan alat- } \\
\text { alat kesehatan. }\end{array}$ \\
\hline 8 & 27 & $\begin{array}{l}\text { a. Perlindungan akan penghormatan atas diri pribadi, hak-hak } \\
\text { kekeluargaan, keyakinan dan praktek agama, adat istiadat serta } \\
\text { kebiasaan. } \\
\text { b. Perlindungan terhadap wanita atas serangan yang melanggar } \\
\text { kesusilaan. }\end{array}$ \\
\hline 9 & 28 & $\begin{array}{l}\text { Perlindungan untuk tidak digunakan dalam menyatakan sasaran } \\
\text { perang. }\end{array}$ \\
\hline 10 & 29 & Perlindungan atas perlakuan pihak-pihak yang bersengketa. \\
\hline 11 & 30 & Perlindungan mendapatkan fasilitas untuk berhubungan secara tertulis. \\
\hline 12 & 31 & $\begin{array}{l}\text { Perlindungan untuk tidak dipaksa secara fisik dan moral untuk } \\
\text { memperoleh keterangan. }\end{array}$ \\
\hline 13 & 32 & Perlindungan dari penderitaan jasmani. \\
\hline 14 & 33 & $\begin{array}{l}\text { a. Perlindungan terhadap intimidasi, teror dan perampokan. } \\
\text { b. Perlindungan terhadap tindakan pembalasan (reprisal). } \\
\text { c. Perlindungan untuk tidak dihukum atas pelanggaran yang tidak } \\
\text { dilakukan sendirian. }\end{array}$ \\
\hline 15 & 34 & Perlindungan untuk tidak dijadikan sandera. \\
\hline
\end{tabular}

Dalam hal perlindungan bagi orang-orang asing yang berada di wilayah pihak yang berperang sedangkan mereka tidak meninggalkan wilayahnya diatur dalam ketentuan pasal 37 konvensi. Yang menyatakan : "orang-orang yang dilindungi yang berada dalam tutupan sambil menunggu atau yang sedang

menjalani hukuman yang meliputi
kehilangan kebebasan, harus
diperlakukan
$\begin{aligned} & \text { perikemanusiaan } \\ & \text { tutupan". }\end{aligned}$

Perlindungan juga diberikan kepada penduduk sipil dalam hal orang asing yang berada di suatu wilayah pendudukan. Sebagaimana diatur 
dalam pasal 35 Konvensi Jenewa IV yang mengatakan bahwa :

"Semua orang yang dilindungi yang berkehendak meninggalkan wilayah pada permulaan, atau selama berlangsungnya suatu sengketa, boleh berbuat demikian, kecuali apabila keberangkatannya itu bertentangan dengan kepentingan-kepentingan nasional dari negara itu. Permohonanpermohonan orang tersebut untuk berangkat harus diputuskan sesuai dengan prosedur-prosedur yang telah ditetapkan secara teratur dan keputusan harus diambil secepat mungkin. Orang-orang yang diizinkan untuk berangkat dapat melengkapi diri mereka dengan dana-dana yang diperlukan untuk perjalanan mereka dan membawa serta satu jumlah yang pantas dari milik dan barang-barang untuk pemakaian pribadi”.

Semua orang dapat memperoleh perlindungan dan apabila mereka ingin meninggalkan wilayah pendudukan maka mereka harus mendapatkan izin dari negara yang bersangkutan. Hal tersebut dikarenakan mereka masih dalam wilayah perlindungan. Perlindungan diberikan kepada seluruh penduduk sipil yang berada di wilayah sengketa dikarenakan keberadaan mereka untuk memberikan pertolongan kepada korban perang. Seperti disebutkan dalam pasal 50 Konvensi Jenewa IV. Selain itu, juga diberikan perlindungan kepada interniran sipil. Yaitu penduduk sipil yang oleh negara penahan dilindungi dengan diberikan penempatan di tempat yang telah ditunjuk negara penahan. Sebagaimana disebutkan dalam pasal 42 :

"Penginterniran orang-orang yang dilindungi atau penempatan mereka di tempat-tempat tinggal yang ditunjuk hanya dapat diperintahkan apabila keamanan Negara Penahan betul-betul memerlukan".

Penduduk sipil yang dapat diinternir adalah mereka (Arlina Permanasari, 1999:175) :

1) Penduduk sipil musuh dalam wilayah pihak yang bersengketa yang perlu diawasi dengan ketat demi kepentingan keamanan (Lihat pasal 41 (1), pasal 42 (2) jo. Pasal 78 Konvensi Jenewa IV tahun 1949)

2) Penduduk sipil musuh dalam wilayah pihak yang bersengketa yang dengan sukarela mengehendaki untuk diinternir; atau karena keadaannya menyebabkan ia diinternir (Lihat pasal pasal 42 (2) Konvensi Jenewa IV tahun 1949).

3) Penduduk sipil musuh dalam wilayah yang diduduki, apabila 
Penguasa Pendudukan menghendaki mereka perlu diinternir karena alasan mendesak.

4) Penduduk sipil yang telah melakukan pelanggaran hukum yang secara khusus bertujuan untuk merugikan Penguasa Pendudukan (Lihat pasal 68 (1) Konvensi Jenewa IV tahun 1949). Orang-orang sipil yang diinternir tetap memiliki kedudukan dan kemampuan sipil mereka sepenuhnya dan dapat melaksanakan hak-hak attendance yang bersangkutan dengan kedudukan sipil yang mereka miliki (pasal 80 Konvensi Jenewa IV tahun 1949). Yang berarti mereka tetap memiliki hak sebagaimana penduduk sipil umumnya, yaitu :

1) Mendapatkan perawatan kesehatan, tunjangan, upah dan pekerjaan (pasal 81 Konvensi Jenewa IV tahun 1949);

2) Mendapatkan fasilitas guna kehidupan keluarga yang layak (pasal 82 Konvensi Jenewa IV tahun 1949);

3) Tidak ditempatkan dalam daerah yang terancam bahaya perang (pasal 83 Konvensi Jenewa IV tahun 1949);

4) Mendapatkan kebebasan melaksanakan ibadah keagamaan (pasal 86 Konvensi Jenewa IV tahun 1949);

5) Mendapatkan fasilitas yang layak untuk melakukan kegiatan perdagangan(pasal 87 Konvensi Jenewa IV tahun 1949);

6) Tempat tinggal yang bebas bahaya kebakaran (pasal 88 Konvensi Jenewa IV tahun 1949);
7) Mendapatkan kebutuhan sandang dan pangan yang layak (pasal 8990 Konvensi Jenewa IV tahun 1949);

8) Mendapat kebersihan dan pengamatan kesehatan (pasal 9092 Konvensi Jenewa IV tahun 1949);

9) Melaksanakan kegiatan keagamaan, intelektual dan jasmani (pasal 93-96 Konvensi Jenewa IV tahun 1949);

10) Memiliki barang pribadi dan sumber keuangan (pasal 97-98 Konvensi Jenewa IV tahun 1949);

11) Mendapatkan perlakuan administrasi dan disiplin yang sesuai dengan asas-asas perikemanusiaan (pasal 99-104 Konvensi Jenewa IV tahun 1949);

12) Melakukan komunikasi dengan orang-orang yang berada di luar wilayah sengketa dengan pengawasan negara penahan (pasal 105-116 Konvensi Jenewa IV tahun 1949);

13) Mendapatkan sanksi pidana dan sanksi disiplin apabila melakukan pelanggaran (pasal 117-126 Konvensi Jenewa IV tahun 1949);

14) Dalam hal pemindahan mendapatkan perlakuan yang berperikemanusiaan (pasal 127128 Konvensi Jenewa IV tahun 1949);

15) Dalam hal kematian mendapatkan perlakuan yang layak (pasal 129131 Konvensi Jenewa IV tahun 1949); dan

16) Terkait pembebasan, pemulangan dan penempatan di negara netral (pasal 132-135 Konvensi Jenewa IV tahun 1949). 


\section{Perkembangannya, Konvensi Jenewa 1949 mengalami perkembangan dengan dikeluarkannya Protokol Tambahan 1977 yang terdiri :}

a) Protocol Additional to the Geneva Conventions of 12 August 1949, and relating to the Protection of Victims of International Armed Conflicts (Protocol I), 8 June 1977.

b) Protocol Additional to the Geneva Conventions of 12 August 1949, and relating to the Protection of Victims of Non-International Armed Conflicts (Protocol II), 8 June 1977.

Penambahan dimaksudkan sebagai penyesuaian terhadap perkembangan pengertian sengketa bersenjata, pentingnya perlindungan yang lebih lengkap bagi mereka yang luka, sakit dan korban karam dalam suatu peperangan, serta antisipasi terhadap perkembangan mengenai alat dan cara berperang.

Dalam Pasal 35 Protokol I disebutkan :

“(1) Dalam setiap sengketa bersenjata, hak-hak pihak yang terlibat dalam sengketa untuk memilih alat dan cara berperang adalah tidak terbatas.

(2) Hal tersebut untuk mencegah penggunaan persenjataan, proyektil dan material, serta metode perang yang dapat menyebabkan terjadinya korban luka yang berlebihan atau penderitaan yang tidak perlu.

(3) Hal tersebut juga dimaksudkan untuk menghindari metode atau alat perang yang digunakan, dengan maksud atau harapan, meluasnya kerusakan berat pada lingkungan alamiah dalam jangka waktu yang panjang.”

Perlindungan terhadap anak-anak diberikan terkait keterlibatan mereka dalam perang. Bahwa dilarang untuk mendaftarkan anak-anak sebelum usia mereka mencapai 15 tahun. Apabila sebelum usia tersebut mereka terlibat perang, maka mereka harus mendapatkan perlakuan sesuai dengan usianya. Dan dilarang untuk menghukum mati anak-anak yang tertangkap sebelum usia mereka mencapai 18 tahun. Hal ini sebagaimana disebutkan dalam Protokol Tambahan tahun 1977 pasal 77 yang mengatakan :

\section{Art 77}

"2. The Parties to the conflict shall take all feasible measures in order that children who have not attained the age of fifteen years do not take a direct part in hostilities and, in particular, they shall refrain from recruiting them into 
their armed forces. In recruiting among those persons who have attained the age of fifteen years but who have not attained the age of eighteen years the Parties to the conflict shall endeavour to give priority to those who are oldest. 3. If, in exceptional cases, despite the provisions of paragraph 2, children who have not attained the age of fifteen years take a direct part in hostilities and fall into the power of an adverse Party, they shall continue to benefit from the special protection accorded by this Article, whether or not they are prisoners of war."

Hukum humaniter mengatur usia minimum yang sah untuk mendaftar menjadi anggota angkatan bersenjata adalah tidak berusia di bawah 18 tahun. Hukum humaniter internasional juga mengatur terkait jaminan fundamental yaitu serangkaian aturan yang menentukan perlakuan minimal yang harus diberikan kepada setiap orang yang berada dibawah kekuasaan suatu pihak dalam sengketa bersenjata. Aturan ini terdapat dalam Protokol Tambahan I tahun 1977. Tidak boleh ada pengecualian terhadap ketentuanketentuan tersebut, sekalipun karena pertimbangan keamanan negara ataupun faktor kepentingan militer memerlukannya. Sementara itu jaminan perlindungan juga diberikan terhadap objek-objek yang sangat vital bagi kelangsungan hidup penduduk sipil, yakni objek-objek sipil yang tidak boleh dijadikan sasaran serangan militer atau sebagai aksi pembalasan serangan. Hal itu ditegaskan dalam Protokol Tambahan I tahun 1977 artikel 52 :

Art 52. General Protection of Civilian Objects

"1. Civilian objects shall not be the object of attack or of reprisals. Civilian objects are all objects which are not military objectives..."

Objek-objek yang sangat penting seperti lumbung makanan, daerah pertanian yang menghasilkan bahan makanan utama, perkebunan, peternakan, instalasi dan persediaan air minum serta bangunan irigasi lainnya.Protokol Tambahan II tahun 1977 mengatur bahwa “orang-orang yang berada dalam kekuasaan salah satu Pihak yang bersengketa harus diperlakukan manusiawi dalam setiap keadaan”, tanpa membedakannya berdasarkan ras, warna kulit, jenis kelamin, bahasa, agama atau kepercayaan, pandangan politik dan 
sebagainya. Terkait sengketa bersenjata non-internasional, perlindungan yang diberikan kepada penduduk sipil tidak mempunyai perbedaan yang prinsip dengan ketentuan sengketa bersenjata internasional. Hal itu tercantum dalam pasal 3 dari empat Konvensi Jenewa tahun 1949 dan dalam Protokol Tambahan II tahun 1977 pasal 4.

Dalam perkembangannya perlindungan kepada penduduk sipil ketika perang juga dimuat dalam ketentuan Protokol Tambahan I pasal 61 yang menyebutkan adanya suatu organisasi yang disebut dengan istilah Civil Defence. Selain memberikan perlindungan terhadap penduduk sipil secara langsung, namun perlindungan juga diberikan terhadap barang-barang yang dibutuhkan oleh penduduk sipil dalam rangka mempertahankan hidupnya. Sehingga dalam hukum humaniter pun dikenal pembedaan sasaran militer dan objek-objek sipil yang harus mendapatkan perlindungan. Di bawah ini merupakan perlindungan dalam pengaturan ketentuan Hukum Jenewa seperti tabel 2 berikut ini :

Tabel 2

Perjanjian tentang Perlindungan Korban-korban Perang Berdasarkan Konvensi Jenewa 1949

\begin{tabular}{|c|c|c|}
\hline No & Konvensi & Bentuk Perlindungan \\
\hline 1 & $\begin{array}{l}\text { Konvensi I tentang } \\
\text { Perbaikan Keadaan Anggota } \\
\text { Angkatan Perang yang Luka } \\
\text { dan Sakit di Medan } \\
\text { Pertempuran Darat } \\
\text { Jenewa, } 12 \text { Agustus } 1949\end{array}$ & $\begin{array}{l}\text { Melindungi kombatan yang luka dan sakit serta } \\
\text { orang-orang yang menyertai mereka, bangunan } \\
\text { dimana mereka berlindung serta peralatan yang } \\
\text { dipakai mereka. Juga mengatur tentang penggunaan } \\
\text { lambang Palang Merah dan Bulan Sabit Merah. }\end{array}$ \\
\hline 2 & $\begin{array}{l}\text { Konvensi II tentang } \\
\text { Perbaikan Keadaan Anggota } \\
\text { Angkatan Perang di Laut } \\
\text { yang Luka, Sakit dan } \\
\text { Korban Karam }\end{array}$ & $\begin{array}{l}\text { Memperluas perlindungan bagi kombatan yang } \\
\text { menjadi korban kapal karam dan mengatur } \\
\text { mengenai syarat-syarat dimana mereka boleh } \\
\text { ditolong. }\end{array}$ \\
\hline
\end{tabular}

Jenewa, 12 Agustus 1949 
3 Konvensi III tentang Melindungi anggota angkatan bersenjata yang Perlakuan Tawanan Perang menjadi tawanan perang. Menetapkan serangkaian Jenewa, 12 Agustus 1949 peraturan yang mengatur tentang perlakuan serta menetapkan hak dan kewajiban dari pihak yang menawan.

\begin{tabular}{lll}
\hline 4 & $\begin{array}{l}\text { Konvensi IV tentang } \\
\text { Perlindungan Orang-orang } \\
\text { Sipil di Waktu Perang } \\
\text { Jenewa, 12 Agustus 1949 }\end{array}$ & $\begin{array}{l}\text { Menetapkan aturan-aturan yang mengatur } \\
\text { perlindungan bagi penduduk sipil, khususnya } \\
\text { perlakuan terhadap penduduk sipil di daerah } \\
\text { pendudukan yang kehilangan kemerdekaannya, } \\
\text { serta mengatur mengenai pendudukan secara umum. }\end{array}$ \\
\hline 5 Protokol Tambahan pada & $\begin{array}{l}\text { Memperluas perlindungan yang diberikan kepada } \\
\text { Konvensi-konvensi Jenewa } \\
\text { 12 Agustus 1949, tentang } \\
\text { Perlindungan Korban dalam } \\
\text { Sengketa Bersenjata }\end{array}$ & berperang. \\
Internasional & \\
8 Juni 1977 & & \\
Protokol Tambahan pada & Berisiskan jaminan-jaminan fundamental untuk \\
Konvensi-konvensi Jenewa & mereka yang tidak terlibat dalam permusuhan pada \\
12 Agustus 1949, tentang & sengketa bersenjata non-internasional, merumuskan \\
Perlindungan Korban dalam & aturan-aturan yang mengatur perlindungan \\
Sengketa Bersenjata Non- & penduduk sipil pada objek-objek dan instalasi yang \\
Internasional & vital bagi kelangsungan hidupnya. \\
8 Juni 1977 &
\end{tabular}

\section{c) Instrumen Hukum Internasional} lainnya

Selain dalam ketentuan Hukum

Den Haag dan Hukum Jenewa, pengaturan perlindungan terhadap penduduk sipil juga terdapat di beberapa ketentuan. Di dalam

Deklarasi Universal Hak Asasi
Manusia (DUHAM) tahun 1948 pasal 7 menyebutkan bahwa :

"Semua orang sama di depan hukum dan berhak atas perlindungan hukum yang sama tanpa diskriminasi. Semua berhak atas perlindungan yang sama terhadap setiap bentuk diskriminasi yang bertentangan dengan deklarasi ini, dan terhadap segala hasutan yang mengarah pada diskriminasi semacam ini”. 
"Setiap manusia berhak atas semua hak dan kebebasan-kebebasan dengan tidak ada pengecualian apa pun, seperti pembedaan ras, warna kulit, jenis kelamin, bahasa, agama, politik atau pandangan lain, asal-usul kebangsaan atau kemasyarakatan, hak milik, kelahiran ataupun kedudukan lain.”

\section{Pasal 3 berbunyi :}

"Setiap orang berhak atas kehidupan, kebebasan dan keselamatan sebagai individu”.

Perlindungan kepada penduduk sipil merupakan bagian dari perlindungan Hak Asasi Manusia (HAM). Ini dapat dimengerti bahwa Hukum Humaniter Internasional dan HAM merupakan dua cabang yang berbeda dari Hukum Internasional, namun keduanya memiliki tujuan yang sama. Hukum Humaniter Internasional diterapkan dalam situasi sengketa bersenjata yang bersifat internasional maupun non-internasional. HAM menentukan sejumlah aturan untuk mengharmoniskan perkembangan individu dalam masyarakat. Tujuan utama keduanya yaitu untuk melindungi martabat manusia dalam setiap keadaan.
Lebih lanjut lagi, atas dasar perlindungan HAM yang diatur dalam hukum humaniter internasional bahwasanya perampasan hak dan martabat ketika perang merupakan bentuk kejahatan atas nilai-nilai kemanusiaan itu sendiri. Pengaturan atas perlindungan terhadap penduduk; pembatasan pengembangan dan penggunaan senjata; perlindungan atas objek-objek vital bagi penduduk; pengaturan cara dan metode berperang baik di darat, laut maupun di udara merupakan bagian dari upaya manusia dalam melindungi sesamanya serta menjaga agar hak dan martabat manusia untuk dapat hidup sebagai manusia yang layak.

Adapun peraturan internasional lainnya yang terkait pengaturan hukum humaniter internasional yaitu :

1) Instructions for the Government of Armies of the United States in the Field (Lieber Code). 24 April 1863.

2) Resolutions of the Geneva International Conference. Geneva, 26-29 October 1863.

3) Convention for the Amelioration of the Condition of the Wounded in Armies in the Field. Geneva, 22 August 1864. 
4) Additional Articles relating to the Condition of the Wounded in War. Geneva, 20 October 1868.

5) Declaration Renouncing the Use, in Time of War, of Explosive Projectiles Under 400 Grammes Weight. Saint Petersburg, 29 November / 11 December 1868.

6) Project of an International Declaration concerning the Laws and Customs of War. Brussels, 27 August 1874.

7) The Laws of War on Land. Oxford, 9 September 1880.

8) Final Act Of the International Peace Conference. The Hague, 29 July 1899.

9) Convention for the Exemption of Hospital Ships, in Time of War, from The Payment of all Dues and Taxes Imposed for the Benefit of the State. The Hague, 21 December 1904.

10) Convention for the Amelioration of the Condition of the Wounded and Sick in Armies in the Field. Geneva, 6 July 1906.

11) Final Act of the Second Peace Conference. The Hague, 18 October 1907.

12) Treaty relating to the Use of Submarines and Noxious Gases in Warfare. Washington, 6 February 1922.

13) Rules concerning the Control of Wireless Telegraphy in Time of War and Air Warfare. Drafted by a Commission of Jurists at the Hague, December 1922 - February 1923.

14) Protocol for the Prohibition of the Use of Asphyxiating, Poisonous or Other Gases, and of
Bacteriological Methods of Warfare. Geneva, 17 June 1925.

15) Final Act of the Diplomatic Conference. Geneva, 27 July 1929.

16) Convention for the Amelioration of the Condition of the Wounded and Sick in Armies in the Field. Geneva, 27 July 1929.

17) Convention relative to the Treatment of Prisoners of War. Geneva, 27 July 1929.

18) First draft Convention adopted in Monaco (Sanitary cities and localities), 27 July 1934.

19) Draft International Convention on the Condition and Protection of Civilians of enemy nationality who are on territory belonging to or occupied by a belligerent. Tokyo, 1934.

20) Draft Convention for the Protection of Civilian Populations Against New Engines of War. Amsterdam, 1938.

21) Convention on the Prevention and Punishment of the Crime of Genocide, 9 December 1948.

22) Final Act of the Diplomatic Conference of Geneva, 12 August 1949.

23) Resolutions of the Diplomatic Conference. Geneva, 12 August 1949.

24) Draft Rules for the Limitation of the Dangers incurred by the Civilian Population in Time of War. ICRC, 1956.

25) Human Rights in Armed Conflicts. Resolution XXIII adopted by the International Conference on Human Rights. Teheran, 12 May 1968. 
26) Respect for Human Rights in Armed Conflicts. Resolution 2444 (XXIII) of the United Nations General Assembly, 19 December 1968.

27) The Distinction between Military Objectives and Non-Military Objectives in General and Particularly the Problems Associated with Weapons of Mass Destruction. Edinburgh, 9 September 1969.

28) Convention on the Prohibition of the Development, Production and Stockpiling of Bacteriological (Biological) and Toxin Weapons and on their Destruction. Opened for Signature at London, Moscow and Washington. 10 April 1972.

29) Final Act of the Diplomatic Conference of Geneva of 19741977.

30) Resolutions of the Diplomatic Conference of Geneva of 19741977.

31) Convention on the prohibition of military or any hostile use of environmental modification techniques, 10 December 1976.

32) Convention of the OAU for the Elimination of Mercenarism in Africa. Libreville, 3rd July 1977.

33) Resolution on Small-Calibre Weapon Systems. Geneva, 28 September 1979.

34) Final Act of the United Nations Conference on Prohibitions or Restrictions on the Use of Certain Conventional Weapons Which May be Deemed to be Excessively Injurious or to Have Indiscriminate Effects. Geneva, 10 October 1980.
35) Convention on Prohibitions or Restrictions on the Use of Certain Conventional Weapons Which May be Deemed to be Excessively Injurious or to Have Indiscriminate Effects. Geneva, 10 October 1980.

36) Protocol on Non-Detectable Fragments (Protocol I). Geneva, 10 October 1980.

37) Protocol on Prohibitions or Restrictions on the Use of Mines, Booby-Traps and Other Devices (Protocol II). Geneva, 10 October 1980.

38) Protocol on Prohibitions or Restrictions on the Use of Incendiary Weapons (Protocol III). Geneva, 10 October 1980.

39) Convention on the Rights of the Child, 20 November 1989.

40) International Convention against the Recruitment, Use, Financing and Training of Mercenaries, 4 December 1989.

41) Convention on the prohibition of the development, production, stockpiling and use of chemical weapons and on their destruction, Paris 13 January 1993.

42) Protocol on Blinding Laser Weapons (Protocol IV to the 1980 Convention), 13 October 1995.

43) Protocol on Prohibitions or Restrictions on the Use of Mines, Booby-Traps and Other Devices as amended on 3 May 1996 (Protocol II to the 1980 Convention as amended on 3 May 1996).

44) Convention on the Prohibition of the Use, Stockpiling, Production and Transfer of Anti-Personnel 
Mines and on their Destruction, 18 September 1997.

45) Optional Protocol to the Convention on the Rights of the Child on the involvement of children in armed conflict, 25 May 2000.

46) Convention on Prohibitions or Restrictions on the Use of Certain Conventional Weapons Which May be Deemed to be Excessively Injurious or to Have Indiscriminate Effects. Geneva, 10 October 1980. Amendment article 1, 21 December 2001.

47) Protocol on Explosive Remnants of War (Protocol $V$ to the 1980 Convention), 28 November 2003.

48) Protocol additional to the Geneva Conventions of 12 August 1949, and relating to the Adoption of an Additional Distinctive Emblem (Protocol III), 8 December 2005.

\section{d) Berdasarkan Marten's Clause}

HHI mengenal adanya "Marten's clause“.Marten's clause atau Klausula Marten adalah suatu klausula yang menentukan bahwa apabila Hukum Humaniter belum mengatur masalahmasalah tertentu, maka ketentuan yang dipergunakan harus mengacu pada prinsip-prinsip hukum internasional yang terbentuk dari kebiasaan antara negara-negara, hukum kemanusiaan serta dari hati nurani masyarakat.
Khusus mengenai perlindungan terhadap sipil Marten's clause sangat menjunjung nilai-nilai kemanusiaan, misalnya tidak mengarahkan serangan pada warga sipil, mencegah penderitaan yang berlebihan. Adanya penghargaan yang tinggi terhadap nilainilai kemanusiaan juga tampak dalam prinsip-prinsip fundamental hukum internasional misalnya dalam prinsip kemanusiaan, prinsip pembedaan, prinsip proporsional, serta prinsip untuk tidak menimbulkan penderitaan yang tidak seharusnya (Theodor Meron, 2000:78-79)

Perlindungan Hukum Bagi Penduduk Sipil ketika terjadi konflik bersenjata berdasarkan Hukum Pertahanan Indonesia

\section{a) Pertahanan Negara}

Pertahanan Negara atau pertahanan nasional adalah tindakan untuk melenyapkan ancaman musuh dari luar negeri, dalam bentuk dan wujud apapun, yang mengancam dan membahayakan kedaulatan, keselamatan dan eksistensi bangsa dan 
Negara (Jerry Indrawan, 2015:67). Pertahanan juga bisa dikatakan sebagai perang yang dijalankan dengan menangkis pukulan lawan untuk maksud pembelaan (Soewarso, 1982:75). Dalam kaitan pembelaan negara, pertahanan nasional dimaksudkan sebagai kekuatan, kemampuan, daya tahan dan keuletan yang menjadi tujuan suatu bangsa untuk menghadapi tantangan, ancaman, hambatan dan gangguan yang datang dari luar ataupun dari dalam, yang secara langsung atau tidak langsung membahayakan kelangsungan hidup bangsa dan Negara (HAsan Bakti Nasution, 2000:4).

Di dalam Undang-Undang Nomor 3 Tahun 2002 tentang Pertahanan Negara pasal 1 ayat 1 dikatakan bahwa

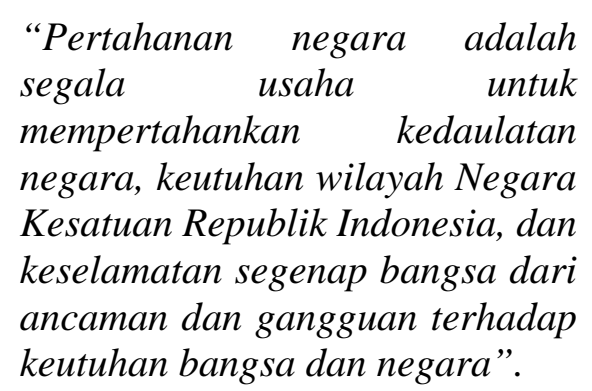

Pertahanan suatu negara berarti menunggu serangan musuh terhadap negara tersebut, selanjutnya apabila fase menunggu itu telah selesai artinya serangan telah datang, maka pertahanan boleh menjalankan setiap kegiatan positif dalam bentuk serangan sebab karakteristik pokok menunggu telah terpenuhi. Oleh karena itu pertahanan itu mengandung 2 (dua) buah karakteristik yang kontras yaitu menunggu (negatif) dan bertindak (positif). Kedua karakteristik tersebut saling tidak dapat dipisahkan, karena tanpa menunggu tidak dapat dikatakan pertahanan sedangkan sebaliknya tanpa bertindak tidak dapat dikatakan perang dan oleh karena pertahanan itu merupakan perang, maka tanpa bertindak tidak dapat juga disebut pertahanan.

Konsepsi pertahanan negara berkaitan dengan bagaimana suatu negara melihat sumber dan jenis ancaman terhadap keamanan nasionalnya (National Security), khususnya yang berkaitan dengan ancaman militer serta bagaimana negara yang bersangkutan menangkal 
atau mengatasi ancaman tersebut. Konsep pertahanan ini tidaklah statis, tetapi dinamis mengikuti perubahanperubahan yang terjadi, baik di lingkungan internal maupun eksternal Dewi Fortuna Anwar, 2002:17). dan persiapan pertahanan negara yang baik amat dipengaruhi oleh efektifnya sistem keamanan nasional dan sistem kesejahteraan nasional. Kalau kesejahteraan nasional rendah karena kemampuan ekonomi, industri dan pemasukan negara (Revenue) kurang baik, tidak mungkin dibangun pertahanan negara yang memadai (Sayidiman Suryohadiprojo, 2005:11) .

\section{b) Sistem Pertahanan Negara di Indonesia}

Didalam Undang-undang Dasar 1945 pasal 30 ayat 2 disebutkan perihal penyelenggaraan pertahanan negara yang berbunyi :

"Usaha pertahanan dan keamanan Negara dilaksanakan melalui sistem pertahanan dan keamanan rakyat semesta oleh Tentara Nasional Indonesia dan Kepolisian Negara Republik Indonesia, sebagai kekuatan utama, dan rakyat sebagai kekuatan pendukung".

Lebih lanjut pasal 1 butir 2 Undang-undang Nomor 3 tahun 2002 tentang Pertahanan Negara menyebutkan juga yaitu :

"Sistem pertahanan negara adalah sistem pertahanan yang bersifat semesta yang melibatkan seluruh warga negara, wilayah, dan sumber daya nasional lainnya, serta dipersiapkan secara dini oleh pemerintah dan diselenggarakan secara total, terpadu, terarah, dan berlanjut untuk menegakkan kedaulatan negara, keutuhan wilayah, dan keselamatan segenap bangsa dari segala ancaman".

Pertahanan bersifat semesta adalah pengikutsertaan seluruh warga negara, pemanfaatan seluruh sumber daya nasional, dan seluruh wilayah negara dalam usaha pertahanan Negara (penjelasan pasal 2 Undang-undang Nomor 3 Tahun 2002 tentang Pertahanan Negara). Dalam perang yang bersifat semesta, seluruh bangsa turut serta dalam pertahanan negara. Tidak hanya para combatan atau pemegang senjata tempur saja yang melakukan pertahanan negara, tetapi 
juga petani, buruh pabrik, pegawai kantor, pelayan telepon, bahkan ibu rumah tangga (Sayidiman Suryohadiprojo, 2005:43). Doktrin ini dirumuskan pertama kali pada rapat kerja pertahanan dan keamanan (Hankam) pada bulan November 1967 di Jakarta. Doktrin ini muncul setelah menganalisa dan mengevaluasi berbagai sistem pertahanan dan keamanan yang telah diterapkan sejak awal kemerdekaan. Akhirnya tercipta sebuah sistem yang lazim dipahami sebagai suatu "entitas" (kesatuan yang utuh dan terpadu) dari sejumlah komponen/unsur yang berproses/bekerja untuk mencapai tujuan tertentu. Dalam sistem ini komponen yang dimaksud terdiri dari TNI (AD, AL dan AU), POLRI, Rakyat Sipil, serta sumber daya alam, sumber daya buatan dan prasarana nasional sebagai komponen pendukung. Doktrin Pertahanan Negara berkedudukan sebagai instrumen dasar dalam mengembangkan seluruh doktrin yang berhubungan dengan pertahanan negara (Safril Hidayat, 2015:84)
Kebijakan strategis penggunaan kekuatan pertahanan diarahkan untuk menghadapi ancaman atau gangguan terhadap keamanan nasional, apapun jenis dan bentuknya kekuatan pertahanan tidak hanya digunakan untuk menghadapi ancaman, tetapi juga untuk membantu pemerintah dalam upaya pembangunan nasional dan tugas-tugas internasional. Dari hasil perkiraan ancaman, Indonesia mempunyai kepentingan strategis untuk mencegah dan mengatasi ancaman keamanan tradisional dan non-tradisional (Buku Putih Pertahanan Indonesia, Mempertahankan Tanah Air Memasuki Abad 21 (Bab V),).

c) Perlindungan Hukum Bagi Penduduk Sipil ketika terjadi konflik bersenjata berdasarkan Hukum Pertahanan Indonesia

\section{1) Berdasarkan Undang-Undang Dasar 1945}

Negara mempunyai tugas: (1) mengendalikan dan mengatur gejalagejala kekuasaan yang bertentangan satu sama lain, supaya tidak menjadi antagonisme yang membahayakan. (2) 
mengorganisir dan mengintegritasikan kegiatan manusia dan golongangolongan ke arah tercapainya tujuantujuan dari masyarakat seluruhnya. Sedangkan fungsi yang harus dijalankan negara yaitu (1), melaksanakan penertiban (law and order) untuk mencapai tujuan bersama dan mencegah bentrokan-bentrokan dalam masyarakat. (2) mengusahakan kesejahteraan dan kemakmuran rakyatnya. (3) pertahanan, untuk menjaga kemungkinan serangan dari luar. (4) menegakkan keadilan

Perlindungan hukum bagi penduduk sipil secara eksplisit dapat terlihat dalam pembukaan UUD 1945 , Perlindungan juga dapat dilihat dalam pembukaan UUD 1945 alinea ke 4 (empat) yang mengatakan bahwa :

"Kemudian dari pada itu untuk membentuk suatu Pemerintah Negara Indonesia yang melindungi segenap bangsa Indonesia dan seluruh tumpah darah Indonesia dan untuk memajukan kesejahteraan umum, dan ikut melaksanakan ketertiban dunia yang berdasarkan kemerdekaan, perdamaian abadi dan keadilan sosial, maka disusunlah Kemerdekaan Kebangsaan Indonesia itu dalam suatu
Undang-Undang Dasar Negara Indonesia..."

Dijelaskan bahwasanya perlindungan hukum merupakan tanggung jawab negara terhadap warga negaranya. UUD 1945 tidak menyebutkan perlindungan yang diberikan kepada penduduk sipil ketika terjadi perang, namun perlindungan tersebut merupakan perlindungan terhadap seluruh warga negaranya, yang terkait pada hak-hak asasi setiap manusia. Bahwasanya setiap orang berhak untuk mendapatkan kehidupan yang layak sebagai seorang manusia (M. Darin AM, 2016:161).

Perlindungan hukum bagi penduduk sipil berdasarkan UndangUndang Dasar 1945 (UUD 1945) juga dapat dilihat di dalam beberapa rumusan pasal. Pengaturannya dimasukkan ke dalam ketentuan perlindungan warga negara secara umum yang dimuat dalam Bab $\mathrm{X}$ mengenai Hak Asasi Manusia (HAM). Pasal-pasal tersebut yaitu :

Pasal 28A : 
"Setiap orang berhak untuk hidup serta berhak mempertahankan hidup dan kehidupannya".

Pasal 28B ayat 2 :

"Setiap anak berhak atas kelangsungan hidup, tumbuh, dan berkembang serta berhak atas perlindungan dari kekerasan dan diskriminasi”.

Pasal 28F :

"Setiap orang berhak untuk berkomunikasi dan memperoleh informasi untuk mengembangkan pribadi dan lingkungan sosialnya, serta berhak untuk mencari, memperoleh, memiliki, menyimpan, mengolah, dan menyampaikan informasi dengan menggunakan segala jenis saluran yang tersedia".

Pasal 28G ayat 1 :

"Setiap orang berhak atas perlindungan diri pribadi, keluarga, kehormatan, martabat, dan harta benda yang dibawah kekuasaannya, serta berhak atas rasa aman dan perlindungan dari ancaman ketakutan untuk berbuat atau tidak berbuat sesuatu yang merupakan hak asasi".

Pasal 28G ayat 2 :

"Setiap orang berhak untuk bebas dari penyiksaan dan perlakuan yang merendahkan derajat martabat manusia dan berhak memperoleh suaka politik dari negara lain".

Pasal $28 \mathrm{H}$ ayat 3 :

"Setiap orang berhak atas jaminan sosial yang memungkinkan pengembangan dirinya secara utuh sebagai manusia yang bermartabat".

Pasal 28I ayat 1 :

"Hak untuk hidup, hak untuk tidak disiksa, hak kemerdekaan pikiran dan hati nurani, hak beragama, hak untuk tidak diperbudak, hak untuk diakui sebagai pribadi dihadapan hukum, dan hak untuk tidak dituntut atas dasar hukum yang berlaku surut adalah hak asasi manusia yang tidak dapat dikurangi dalam keadaan apa pun".

Pasal 28I ayat 2 :

"Setiap orang berhak bebas atas perlakuan yang bersifat diskriminatif atas dasar apa pun dan berhak mendapatkan perlindungan terhadap perlakuan yang bersifat diskriminatif itu".

Pasal 28I ayat 4 :

"Perlindungan, pemajuan, penegakan, dan pemenuhan hak asasi manusia adalah tanggung jawab negara, terutama pemerintah".

Pasal 28J ayat 1 : 
"Setiap orang wajib menghormati hak asasi manusia orang lain dalam tertib kehidupan bermasyarakat, berbangsa, dan bernegara".

Jaminan untuk bebas dari rasa takut, bebas dari penyiksaan atau perlakuan lain yang merendahkan derajat martabat manusia, mendapat jaminan sosial. Perlindungan di dalam konstitusi merupakan upaya untuk melindungi manusia dari potensi penyalahgunaan kekuasaan pemerintah dan membatasi dari kekuasaan negara. Secara tegas UUD 1945 menyatakan adanya hak asasi yang tidak dapat dikurangi (non derogable human rights) yang meliputi hak untuk hidup, hak untuk tidak disiksa, hak kemerdekaan pikiran dan hati nurani, hak beragama, hak untuk tidak diperbudak, hak untuk diakui sebagai pribadi dihadapan hukum, dan hak untuk tidak dituntut atas dasar hukum yang berlaku surut.

UUD 1945 juga di dalamnya membedakan secara tegas antara hak asasi manusia (Human Rights) dan hak warga negara (Citizens Rights). Hak warga Negara merupakan hak yang muncul ketika adanya sebuah kontrak sosial dan konsensus politik yang berwujud dalam sebuah negara. Hak warga negara ini hanya berlaku bagi warga negara dari negara yang bersangkutan, dan tidak berlaku bagi warga negara asing yang berada di dalam negara tersebut.

\section{2) Undang-Undang Nomor 27}

Tahun 1997 tentang Mobilisasi

\section{dan Demobilisasi}

Pengerahan kekuatan rakyat dalam usaha pembelaan negara diatur dalam Undang-Undang Nomor 27 Tahun 1997 tentang Mobilisasi dan Demobilisasi. Pasal 1 ayat 2 menyatakan bahwa :

"Mobilisasi adalah tindakan pengerahan dan penggunaan secara serentak sumber daya nasional serta sarana dan prasarana nasional yang telah dibina dan dipersiapkan sebagai komponen kekuatan pertahanan keamanan negara untuk digunakan secara tepat, terpadu dan terarah bagi penanggulangan setiap ancaman, baik dari luar negeri maupun dari dalam negeri”.

Dalam hal melaksanakan mobilisasi, maka dilakukan ketika 
terjadi keadaan bahaya yakni (pasal 1 ayat 1 Undang-Undang Nomor 27 Tahun 1997 tentang Mobilisasi dan Demobilisasi) :

"Suatu keadaan yang dapat menimbulkan ancaman terhadap persatuan dan kesatuan bangsa serta kelangsungan hidup bangsa dan Negara Republik Indonesia sesuai dengan Undang-undang Keadaan Bahaya”.

Mobilisan adalah warga negara anggota Rakyat Terlatih, warga negara anggota Perlindungan Masyarakat, dan warga negara yang karena keahliannya dimobilisasi (pasal 1 ayat 4 UndangUndang Nomor 27 Tahun 1997 tentang Mobilisasi dan Demobilisasi). Sedangkan demobilisasi adalah tindakan penghentian pengerahan dan penghentian penggunaan sumber daya nasional serta sarana dan prasarana nasional yang berlaku untuk seluruh wilayah negara yang diselenggarakan secara bertahap guna memulihkan fungsi dan tugas setiap unsur seperti sebelum berlakunya mobilisasi (pasal 1 ayat 5 Undang-Undang Nomor 27 Tahun 1997 tentang Mobilisasi dan Demobilisasi).
Rakyat Terlatih adalah komponen dasar kekuatan pertahanan keamanan negara, yang mampu melaksanakan fungsi ketertiban umum, perlindungan rakyat, keamanan rakyat dan perlawanan rakyat dalam rangka penyelenggaraan pertahanan keamanan Negara (pasal 1 ayat 7 Undang-Undang Nomor 27 Tahun 1997 tentang Mobilisasi dan Demobilisasi), serta Perlindungan Masyarakat adalah komponen khusus kekuatan pertahanan keamanan negara yang mampu berfungsi membantu masyarakat menanggulangi bencana dan memperkecil akibat malapetaka (pasal 1 ayat 8 Undang-Undang Nomor 27 Tahun 1997 tentang Mobilisasi dan Demobilisasi).

Mobilisasi diselenggarakan dengan tujuan untuk menanggulangi setiap ancaman yang membahayakan persatuan dan kesatuan bangsa serta kelangsungan hidup bangsa dan Negara Kesatuan Republik Indonesia. Sedangkan Demobilisasi diselenggarakan dengan tujuan untuk memulihkan kembali fungsi dan tugas umum pemerintahan, kehidupan 
kemasyarakatan, dengan tetap terpeliharanya kemampuan dan kekuatan pertahanan keamanan Negara (pasal 4 Undang-Undang Nomor 27 Tahun 1997 tentang Mobilisasi dan Demobilisas). Mobilisasi dan demobilisasi mengandung makna upaya bangsa dalam mempertahankan kemerdekaan, melindungi segenap hak dan kewajiban setiap warga negara dalam usaha bela negara sesuai dengan amanat yang terkandung dalam Pancasila dan Undang-Undang Dasar 1945 (penjelasan umum butir 4 Undang-Undang Nomor 27 Tahun 1997 tentang Mobilisasi dan Demobilisasi).

3) Undang-Undang Nomor 56 Tahun 1999 tentang Rakyat

\section{Terlatih}

Ikut serta rakyat dalam bela negara di atur dalam Undang-Undang Nomor 56 Tahun 1999 tentang Rakyat Terlatih pasal 1 ayat 1 . Dalam UU tersebut dinyatakan bahwa :

"Rakyat Terlatih adalah
komponen dasar kekuatan
pertahanan keamanan negara
yang mampu melaksanakan fungsi
ketertiban umum, perlindungan

rakyat, keamanan rakyat, dan perlawanan rakyat dalam rangka penyelenggaraan pertahanan keamanan negara".

Rakyat Terlatih merupakan bentuk dari bela negara yang merupakan sikap dan perilaku warga negara yang dijiwai oleh kecintaannya kepada negara kesatuan Republik Indonesia yang berdasarkan Pancasila dan UndangUndang Dasar 1945 dalam menjamin kelangsungan hidup bangsa dan negara. Rakyat Terlatih dibentuk dengan tujuan untuk meningkatkan daya dan kekuatan tangkal bangsa dan negara, membantu Tentara Nasional Indonesia dan Kepolisian Negara Republik Indonesia, menjaga persatuan dan kesatuan bangsa, dan menjamin keamanan dan ketertiban masyarakat dalam rangka pertahanan keamanan Negara (pasal 2 Undang-Undang Nomor 56 Tahun 1999 tentang Rakyat Terlatih). Rakyat Terlatih merupakan salah satu wadah dan bentuk keikutsertaan warga negara sebagai perwujudan hak dan kewajiban dalam usaha pembelaan negara yang menunjukkan sifat kesemestaan dan keserbagunaan dalam penyelenggaraan 
pertahanan keamanan Negara (pasal 3 Undang-Undang Nomor 56 Tahun 1999 tentang Rakyat Terlatih).

Pembentukan anggota Rakyat Terlatih dilaksanakan melalui Wajib Prabakti bagi warga negara yang memenuhi persyaratan. Untuk menjadi anggota Rakyat Terlatih, sekurangkurangnya harus memenuhi persyaratan sebagai berikut: a. warga negara; b. bertaqwa kepada Tuhan Yang Maha Esa; c. setia kepada Pancasila dan Undang-Undang Dasar 1945; d. berumur 18 (delapan belas) tahun sampai dengan 45 (empat puluh lima) tahun; e. berkelakuan baik; f. sehat jasmani dan rohani; dan g. tidak dalam keadaan kehilangan haknya untuk ikut serta dalam usaha pembelaan Negara (pasal 5 Undang-Undang Nomor 56 Tahun 1999 tentang Rakyat Terlatih).

\section{4) Undang-Undang No.3 tahun}

\section{2 tentang Pertahanan Negara}

Setiap warga negara berhak dan wajib dalam usaha mempertahankan negara. Hal membuka peran warga negara untuk terlibat secara langsung ketika negara sedang mengalami peperangan. Dalam pasal 1 ayat 1 Undang-undang Nomor 3 tahun 2002 tentang Pertahanan Negara menyebutkan bahwa :

"Pertahanan negara adalah
segala untuk
mempertahankan kedaulatan
negara, keutuhan wilayah Negara
Kesatuan Republik Indonesia, dan
keselamatan segenap bangsa dari
ancaman dan gangguan terhadap
keutuhan bangsa dan negara".

Selanjutnya ayat 2 menerangkan :

"Sistem pertahanan negara adalah sistem pertahanan yang bersifat semesta yang melibatkan seluruh warga negara, wilayah, dan sumber daya nasional lainnya, serta dipersiapkan secara dini oleh pemerintah dan diselenggarakan secara total, terpadu, terarah, dan berlanjut untuk menegakkan kedaulatan negara, keutuhan wilayah, dan keselamatan segenap bangsa dari segala ancaman".

Penyelenggaraan pertahanan negara adalah segala kegiatan untuk melaksanakan kebijakan pertahanan negara, dan pengelolaan pertahanan negara adalah segala kegiatan pada tingkat strategis dan kebijakan yang meliputi perencanaan, pelaksanaan, 
pengawasan, dan pengendalian pertahanan negara.

Dalam pelaksanaan pertahanan negara dikenal komponen utama, cadangan dan pendukung. Komponen utama adalah Tentara Nasional Indonesia yang siap digunakan untuk melaksanakan tugas-tugas pertahanan (pasal 1 ayat 5 Undang-Undang Nomor 3 Tahun 2002 tentang Pertahanan Negara. Komponen cadangan adalah sumber daya nasional yang telah disiapkan untuk dikerahkan melalui mobilisasi guna memperbesar dan memperkuat kekuatan dan kemampuan komponen utama (pasal 1 ayat 6 Undang-Undang Nomor 3 Tahun 2002 tentang Pertahanan Negara). Serta Komponen pendukung adalah sumber daya nasional yang dapat digunakan untuk meningkatkan kekuatan dan kemampuan komponen utama dan komponen cadangan (pasal 1 ayat 7 Undang-Undang Nomor 3 Tahun 2002 tentang Pertahanan Negara).

Sumber daya nasional adalah sumber daya manusia, sumber daya alam, dan sumber daya buatan. (pasal 1 ayat 10 Undang-Undang Nomor 3
Tahun 2002 tentang Pertahanan Negara).

Hakikat pertahanan negara adalah segala upaya pertahanan bersifat semesta yang penyelenggaraannya didasarkan pada kesadaran atas hak dan kewajiban warga negara serta keyakinan pada kekuatan sendiri (pasal 2 Undang-Undang Nomor 3 Tahun 2002 tentang Pertahanan Negara). Yang dimaksud dengan bersifat semesta adalah pengikutsertaan seluruh warga negara, pemanfaatan seluruh sumber daya nasional, dan seluruh wilayah negara dalam usaha pertahanan negara.

Pasal 7 ayat 2 menyebutkan bahwa "Sistem pertahanan negara dalam
menghadapi ancaman militer
menempatkan Tentara Nasional
Indonesia sebagai komponen
utama dengan didukung oleh
komponen cadangan dan
komponen pendukung". Berdasarkan rumusan ketentuan pasal diatas dapat dilihat bahwa penyelenggaraan pertahanan memiliki tujuan melindungi keselamatan seluruh 
warga negara dari segala bentuk ancaman..

Strategi system pertahanan Kemanaman Rakyat Semesta dilakukan melalui upaya-upaya :

(1) memperkuat komponen TNI dan Polri, (2) memperkuat komponen cadangan meliputi warga negara, sumber daya alam serta sarana dan prasarana, (3) memperkuat komponen pendukung yaitu warga Negara, sumberdaya alam, sumberdaya buatan serta sarana prasarana nasional sebagai peningkatan kekuatan komponen cadangan dan komponen pendukung (Djoharis Lubis, 2016:46). Sistem pertahanan negara yang terdiri atas komponen utama, komponen cadangan, dan komponen pendukung. Menempatkan hanya TNI saja yang ditetapkan sebagai komponen utama, sedangkan cadangan Tentara Nasional Indonesia dimasukkan sebagai komponen cadangan. Hal tersebut dimaksudkan agar pelaksanaan penyelenggaraan pertahanan negara sesuai dengan aturan hukum internasional yang berkaitan dengan prinsip pembedaan perlakuan terhadap kombatan dan non-kombatan, serta untuk penyederhanaan pengorganisasian upaya bela Negara (penjelasan umum Undang-Undang Nomor 3 Tahun 2002 tentang Pertahanan Negara).

Meskipun terlihat sistem pertahanan negara sudah menerapkan prinsip pembedaan namun tidaklah secara tegas sebagaimana yang digunakan dalam ketentuan hukum humaniter internasional. Pembedaan yang dilakukan dalam hukum humaniter mempunyai implikasi terhadap fungsi dari masing-masing pihak. Dan fungsi dari penduduk sipil merupakan fungsi sipil murni dan tidak terlibat dalam pertempuran.

Dapat dilihat bahwa keberadaan TNI yang berperan sebagai kombatan didalam hukum humaniter internasional masih dalam kesatuan fungsi yang utuh dan menyatu dengan rakyat. Hal ini dapat mengakibatkan hilangnya perlindungan hukum yang seharusnya didapatkan penduduk sipil sebagaimana dijaminkan ketentuan hukum humaniter internasional. Indonesia sendiri sebenarnya telah 
menyepakati ketentuan hukum tersendiri dalam Konvensi IV Jenewa. humaniter internasional dengan Dan ketiga, Instrumen Hukum diratifikasinya Konvensi Jenewa 1949 Internasional lainnya yakni ketentuan dan dikeluarkannya Undang-Undang hukum humaniter diluar dari ketentuan Nomor 59 Tahun 1958 tentang ikut serta Negara Republik Indonesia dalam seluruh Konvensi Jenewa tanggal 12 Agustus 1949. Dalam hal ini keberadaan doktrin sishankamrata adalah bertentangan dengan konvensi ini dimana di dalam konvensi ini diatur secara tegas pembedaan antara pihak kombatan dan non-kombatan ketika perang berlangsung.

\section{Simpulan}

Perlindungan hukum bagi penduduk sipil (Civilian) pada saat konflik bersenjata dalam instrumen hukum internasional diatur dalam ketentuan yang disebut Hukum Humaniter Internasional. Hukum humaniter tersebut dikodifikasi ke dalam : Pertama, Hukum Den Haag yaitu ketentuan hukum humaniter yang mengatur mengenai metode dan alat berperang. Kedua, Hukum Jenewa yaitu ketentuan hukum humaniter yang mengatur perlindungan korban perang. Perlindungan penduduk sipil diatur Hukum Den Haag maupun Hukum Jenewa. Sedangkan, perlindungan hukum bagi penduduk sipil (Civilian) pada saat konflik bersenjata berdasarkan Sistem Pertahanan Negara di Indonesia mengacu kepada ketentuan perlindungan terhadap hak asasi manusia (HAM) secara umum. Hal tersebut terlihat pada pengaturan di dalam Undang-Undang Dasar tahun 1945, maupun Undang-Undang Nomor 56 Tahun 1999 tentang Rakyat Terlatih. Sementara dalam Undang-Undang Nomor 27 Tahun 1997 tentang Mobilisasi dan Demobilisasi dan Undang-Undang Nomor 3 Tahun 2002 tentang Pertahanan Negara

\section{Daftar Pustaka}

\section{Buku}

Araf, Al, 2005, Dilema dalam Menata Ulang Sistem Pertahanan dan Kemanan Negara, dalam Dinamika Reformasi Sektor Keamanan, Jakarta: Imparsial. 
Permanasari, Arlina, 1999, Pengantar Hukum Humaniter Internasional, Jakarta: ICRC.

Departemen Pendidikan Nasional, 1995, Kamus Besar Bahasa Indonesia, Cetakan Kelima, Balai Pustaka, Jakarta, 1995.

Haryomataram, 1984 Hukum Humaniter, Jakarta: CV.Rajawali. 2002, Konflik Bersenjata dan Hukumnya, Jakarta: Universitas Trisakti, Jakarta.

2005, Pengantar Hukum Humaniter, Jakarta: Rajawali Pers. Jakarta.

Sugeng, Istanto, F., 1998, Hukum Internasional, Jogjakarta :Universitas Atma Jaya.

Anggoro, Kusnanto, 2001, Memisahkan Negara dari Rakyat, sebuah pengantar dalam Lukas Luwarso, Negara Dalam Bahaya, Kontroversi Seputar RUU Penanggulangan Keadaan Bahaya, Jakarta: Lembaga Studi dan Advokasi Masyarakat (ELSAM).

Effendi, Mansyur, 1994, Hukum Humaniter Internasional Dan Pokok-Pokok Doktrin HANKAMRATA, Surabaya: Usaha Nasional.

Faqih, Mariyadi, dkk, 2003 Perang Sebagai Pelanggaran HAM,
Malang: Lembaga Penerbitan Fakultas Hukum Universitas Islam Malang.

Hadjon, Philipus M., 1987, Perlindungan Hukum Bagi Rakyat di Indonesia, Surabaya: Bina Ilmu.

Marzuki, Peter Mahmud, 2005, Penelitian Hukum, Jakarta: Kencana Prenada Media Group.

Suryohadiprojo, Sayidiman, 2005, Si Vis Pacem Para Bellum: Membangun Pertahanan Negara yang Modern dan Efektif, Jakarta: PT. Gramedia Pustaka Utama.

Soewarso, 1982, Wawasan Nusantara, Ketahanan Nasional, Keamanan Nasional, Jakarta: Alumni Sekolah Tinggi Teknologi TNI AL.

Soekanto, Soeryono, 1990, Penelitian Hukum Normatif (Suatu Tinjauan Singkat), Jakarta: C.V Rajawali, 1990

Rudy,T. May, 2002, Studi Strategis Dalam Transformasi Sistem Internasional Pasca Perang Dingin, Bandung: Refika Aditama.

Muhaimin, Yahya A, 2002, Perkembangan Militer dalam Politik di Indonesia 19451966, Yogyakarta:, Gadjah 
Mada University Press, Yogyakarta.

\section{Jurnal dan lainnya}

Anastasya Y.Turlel, 2017, Perlindungan Penduduk Sipil dalam Situasi Perang menurut Konvensi Jenewa Tahun 1949, Jurnal Lex Crimen, Vol. VI No.2, Maret-April 2017

Danial, 2016, Efektifitas Konsep Prinsip Pembedaan Hukum Humaniter Internasional sebagai Upaya Perlindungan Korban dalam konflik Bersenjata Modern, Jurnal Media Hukum, Vol.23 No.2, Desember 2016.

Djoharis Lubis, 2016, Ketahanan Nasional: Permasalahan dan Solusinya dan Perspektif Kependudukan, Jurnal Kajian Lemhanas RI, Edisi 26, Juni 2016.

Jerry Indrawan, 2015, Kepemimpinan berbasis Pemberdayaan dan Teknologi: sebuah upaya meningkatkan kulaitas SDM Pertahanan Indonesia, Jurnal Pertahanan, Vol. 5 No.1, 2015.

M.Darin AM, 2016, Hubungan Konstitusi Dengan Tugas dan Fungsi Negara, Jurnal Ahkam, Vol.4 No.1, Juli 2016.

Rina Rusman, 2004, Konsep Pelanggaran Berat Hak Asasi Manusia Dilihat Dari Sisi Hukum Humaniter, Jurnal
HAM, vol. 2 No. 2 November 2004.

Rotem Giladi, 2014, The enactment of irony : refelctions on the origins of the Marten's Clause, European Journal of International Law, Vol.25, 2014.

Safril Hidayat, 2015, Doktrin Pertahanan dalam mewujudkan keamanan maritime: Perspektif Posmodernisme, Jurnal Pertahanan, Vol 5 No.2, Agustus 2015.

Teguh Sulista, 2007, Pengaturan perang dan konflik bersenjata dalam Hukum Humaniter Internasional, Jurnal Hukum Internasional, Vo.4 No3, April 2007.

Theodor Meron, 2000, The mArtens Clause, principles of humanity, and dictates of public conscience, The American Journal of International Law, Vol.94 No.1, January 2000.

Andi Widjajanto, Potensi Pelanggaran Etika Dalam Sishankamrata, tanggal 14 Agustus 2000, www.kompas.com.

International Humanitarian Law Treaties \& Documents, www.icrc.org.

Buku Putih Pertahanan Indonesia, Mempertahankan Tanah Air 
Memasuki Abad 21 (Bab V), www.dephan.go.id.

Imparsial, Rencana Pembentukan UU Komponen

Cadangan

(Wamil/Bela Negara), Pers

Release

No.

127/Imparsial/XI/2007, www.imparsial.org 